\title{
Er kollaborativ refleksiv læring noget der findes - eller bare noget vi taler om?
}

\author{
Anne Ejsing \\ Institut for Læring \\ Aalborg Universitet \\ anne.ejsing@learning.auc.dk
}

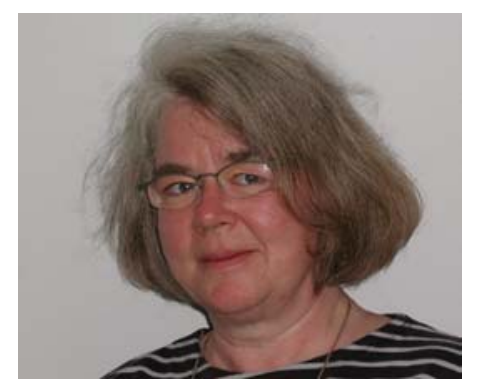

Anne Ejsing er gymnasielektor, cand.mag. og Master i Lareprocesser samt ph.d.-stipendiat.

Hvad foregår der, når studerende arbejder i grupper? I almindelighed ved vi det ikke og kan kun bedømme resultatet i form af oplæg, opgaver, rapporter og procesbeskrivelser. Når gruppearbejdet foregår computermedieret - f.eks. som CSCL (Computer Supported Collaborative Learning) - har man dog på grund af den skriftlige kommunikations permanens en enestående chance for at iagttage hvad der er foregået, og vurdere både samarbejdet og den læring, der kan spores.

I mit masterspeciale ved VCL - nu Institut for Læring - ved Aalborg Universitet har jeg undersøgt samarbejde, refleksion og læring i en gruppekonference i konferencesystemet FirstClass (FC) ud fra både en teoretisk og en empirisk nysgerrighed: Hvad er den læringsteoretiske baggrund for at hævde værdien af gruppearbejde, og kan man påvise et refleksivt læringspotentiale i computermedieret gruppearbejde empirisk?

Resultaterne af undersøgelsen har naturligvis ikke almen gyldighed, men kan give nogle fingerpeg om, at det er muligt at forestille sig kollaborativ refleksiv læring som andet end ren teori. Samtidig er der dog en del faktorer, som i den konkrete gruppe stiller sig i vejen for denne læring. Dels viser alt for formmæssigt færdige skriftlige oplæg sig at være en hindring for kollaborativ refleksion, dels spiller skriftlighedens permanens ikke godt sammen med de møder, der afholdes, når tingene går i kage, dels virker nogle af de studerendes læringsvaner bremsende for en kollaborativ læreproces, og endelig er gruppen famlende overfor anvendelsen af FirstClass. Noget kunne tyde på, at der her ligger en pædagogisk opgave for undervisere og vejledere: Kollaborative kompetencer og IKT-færdigheder er ikke en selvfølge, heller ikke blandt studerende på universitetsniveau.

\section{Indledning}

Er der én ting, der er konsensus om i dagens pædagogiske diskurs, så er det, at 'gruppearbejde er godt, mere gruppearbejde er bedre og projektarbejde er bedst'. Selv mere traditionelt tænkende lærere griber til gruppearbejdet som pædagogisk middel, for som en 60-årig kollega i gymnasiet desillusioneret sagde forleden: "Det bliver nogle mere interessante diskussioner, 
når eleverne har haft gruppearbejde, selv om det egentlig består af den forberedelse, de ikke mere laver hjemme."

Men hvad mener man egentlig, når man siger 'gruppearbejde'?

I Den store danske Encyklopædi (bd. 7) bliver gruppearbejde defineret som en "pædagogisk arbejdsform, der kræver samarbejde for at nå et fælles mål. ... (Det kan) betragtes som en praktisk træning i demokratiske beslutningsprocesser ... Gruppearbejdsformen er inspireret af pædagogiske filosoffer, der understreger skolens ansvar for børns sociale udvikling." Encyklopædiens version af den dominerende pædagogiske diskurs betragter altså gruppearbejde som udvikling af sociale kompetencer med en læringsteoretisk baggrund, som primært er 'inspireret af' Piaget.

Pædagogisk-didaktisk praksis går imidlertid ud fra, at gruppearbejde også har en anden dimension; at der foregår en kognitiv eller 'faglig' læring i gruppen. Men der gøres sjældent egentlige forsøg på at underbygge antagelsen læringsteoretisk. Illeris (1974) argumenterede i klassikeren 'Problemorientering og deltagerstyring' for et varieret og afvekslende læringsmiljø med masser af gruppearbejde ved at udnævne det til "et så banalt forhold, at det skulle være overflødigt at påpege det." (Ibid.: 129). 27 år senere skriver Birch Andreasen (2001) i forbindelse med undervisningsministeriets it-strategi, at dialog og samarbejde er centralt for de studerendes viden, uden at begrunde udsagnet - det betragtes også af ham som en selvfølgelig sandhed. Tilsvarende tendenser ses i EVA-instituttets anbefalinger (f.eks. Historie med samfundskundskab ... 2001).

Men hvis gruppe- og projektarbejde skal være norm i undervisningssystemet, må det være påtrængende at søge et egentligt læringsteoretisk belæg for, at gruppe- og projektarbejde har et læringspotentiale, som ikke tilgodeses på anden vis. Ganske vist anskuer Encyklopædien det udelukkende som læring af sociale kompetencer og dermed hørende til socialiseringsområdet - i praksis handler det om 'learning by doing', og de færreste lærere blander sig i gruppernes proces. I forhold til en kognitiv læringsdimension stiller sagen sig dog anderledes, og her er der ikke megen hjælp at hente hos de gængse teoretikere.

Illeris (1999: 181). betragter f.eks. i dag læring som en "integreret proces, der altid indbefatter både en kognitiv, en psykodynamisk og en social og samfundsmæssig dimension. Den omfatter dels en direkte eller medieformidlet samspilsproces mellem individet og dets materielle og sociale omgivelser, dels en indre psykisk tilegnelsesproces." Grundlæggende er udgangspunktet hos Illeris dog, at (kognitiv) læring ér en individuel proces, mens den sociale og samfundsmæssige dimension betragtes som kontekst for, formål med og handlingsperspektiv for læring. I virksomhedsteori og mesterlære er synsvinklen ganske vist, at læring er social, men da det foregår i en grundlæggende asymmetrisk relation mellem lærer/dygtigere kammerat og elev (Vygotsky) eller mester og en måske nok legitim, men stadig perifér lærling (Lave), har det ikke så meget relevans for forståelsen af det principielt set symmetriske forhold mellem deltagerne i et gruppearbejde.

Forsøg på at betragte gruppearbejde som et tilfælde af læring i praksisfællesskaber forbliver også indtil videre et postulat $\mathrm{i}$ institutionaliserede lærings- og undervisningssammenhænge. Wenger (2000) stiller netop læring i praksisfællesskaber op som en modsætning til institutionaliseret undervisning, og beskriver praksisfællesskabet som noget der opstår med udgangspunkt $i$ en oplevelse af fælles mål, fælles handlinger, fælles interesser. Man vil måske kunne argumentere for, at længerevarende projektarbejde kan udvikle sig til oplevelsen af praksisfællesskab. Men dette særtilfælde retfærdiggør ikke, at gruppearbejde som sådan defineres som et praksisfællesskab. 
De læringsteoretiske vanskeligheder modsvares af tilsvarende vanskeligheder med at påvise den læringsmæssige værdi af gruppearbejde ad empirisk vej. Det er svært at forstille sig et forsøg, hvor læring i undervisning med gruppearbejde sammenlignes med læring uden gruppearbejde, for hvordan isolerer man det som læres i gruppen fra den øvrige læring, og hvordan sammensætter man to grupper, der på alle andre områder har ensartede vilkår for læring? Spørgeskemaer eller kvalitative interviews af elever eller studerende om deres læring i gruppearbejde løber ind $\mathrm{i}$ et fundamentalt problem med, om det overhovedet er muligt at udtale sig om egen læring, der ér sket? Anvendelsen af observation betyder nærmest paradigmatisk, at gruppens arbejde vil blive påvirket af observatørens tilstedeværelse. Den metodiske diskussion er omfattende, og vil ikke blive yderligere udfoldet her. Måske kan man også nøjes med at forholde sig til, hvor mange danske undersøgelser der rent faktisk har beskæftiget sig med læring (ikke undervisning) i grupper.

I en artikel i bogen 'Refleksive læreprocesser' (Christiansen et al. 1997) forekommer dog en række citater fra og referater af grupperefleksioner over matematiske fænomener, som ser ud til at være optaget med mikrofon - og altså (næsten!) uden observatørens forstyrrende tilstedeværelse. Det er formentlig det tætteste, man kan komme på at registrere, hvad der rent faktisk foregår, selv om alene bevidstheden om at blive optaget på bånd ikke vil kunne undgå at påvirke gruppens deltagere.

De empiriske vanskeligheder mindskes dog, hvis man flytter fokus til computermedierede læringsomgivelser - herefter kaldet 'virtuelle'. På grund af skriftlighedens permanens har man her en enestående mulighed for at iagttage den faktiske kommunikation, og hvis man foretager sin undersøgelse efter gruppearbejdets afslutning, kan man også sikre sig mod, at observatørens blik påvirker processen. Der er naturligvis stadig tale om tolkning af kommunikationen, men en række påvirkningsmuligheder og usikkerhedsfaktorer er mindsket, ligesom konklusionerne vil kunne efterprøves, fordi det materiale de bygger på, principielt er tilgængeligt for andre.

\section{Metodiske overvejelser - forholdet mellem teori og praksis}

Traditionelt har pædagogisk teori på og pædagogisk praksis været to adskilte verdener med perifér tilknytning. Når Bruner definerer undervisningsteori som "foreskrivende i den forstand, at den fremlægger regler vedrørende den mest effektive måde, på hvilken viden eller færdighed kan anvendes" (Bruner 1966, citeret i Illeris 1976, s. 56), så reagerer lærere med teorifremmedhed: "Fornyelser sker, hvis det nye passer ind i det praktiske koncept, som læreren arbejder efter - og hvis personer, man respekterer, går ind for dem. ... Læreres subjektive pædagogiske teori udvikles fortrinsvis gennem refleksion over praksis." (Kelchtermans, citeret i Heise 1998, s.215f).

Pædagogisk forskning udvikler i øjeblikket et alternativt syn på forholdet mellem pædagogisk teori og praksis. I bogen 'Refleksive læreprocesser' ses det som udtryk for en postempirisk videnskabsfilosofi (Jacobsen 1997: 17) med "etnografiske kvaliteter" (Ziehe 1997: 25), hvor refleksioner over praksisfeltet bliver den styrende faktor I, hvad der betegnes som 'refleksiv pædagogisk forskning'. Spørgsmålet er, om ikke pædagogisk forskning hermed risikerer at blive reduceret til praksisfetichisme, hvor teorier kasseres på samme måde som teorifetichisme usynliggør praksis som mindre virkelig end den 'virkelige, videnskabelige virkelighed' (Tyler 1977: 99). Hvis ikke vi kan anvende 'teoriens briller', selv om de som al iagttagelse indebærer en blind plet (Rognhaug 1997: 123), løber vi en risiko for enten at udvikle et kikkertsyn på praksisfeltet, så mønstre og strukturer forsvinder, eller at blive så detaljerede og 
omfattende i praksisforståelsen at det bremser for evnen til at konkludere eller udtrykke andet end indfølende forståelse.

Min undersøgelse har derfor søgt at afbalancere en teoretisk og en praksisorienteret synsvinkel. Men da "teori og praksis har sitt utspring i bakenforliggende oppfattninger vi ofte ikke har en klar bevissthet om" (Bateson: Mind and Nature, her ref. i Schibbye 1997: 135), indbefatter den også et metablik på teori og praksis samt empiri i form af (et udsnit af) den faktisk eksisterende virkelighed.

Denne metodiske tilgang er bl.a. inspireret af Niklas Luhmanns måde at iagttage verden på. Jeg skal ikke her komme med lange udredninger, men er nødt til at gøre klart, at Luhmanns begreber samt ikke mindst den luhmannske måde at forholde sig til kommunikation på, spiller en væsentlig rolle for min analyse, selv om jeg på ingen måde betragter mig selv som systemteoretiker. Begreberne vil i det følgende optræde så lidt som muligt, men bliver til gengæld brugt uden forklaringer, bortset fra en kort introduktion til kommunikationsbegrebet. Interesserede eller frustrerede henvises til Jens Rasmussens eller Ole Thyssens introduktioner (Rasmussen 1998, Thyssen 1997, Ejsing 2001).

\section{Teoretisk tilgang - med praksiskorrektioner}

\section{Kollaborativ læring}

Undersøgelsen er foretaget med udgangspunkt i det felt, der betegnes som CSCL (Computer Supported Collaborative Learning). Jeg vælger derfor i det efterfølgende at udskifte ordet gruppearbejde med kollaboration. Det ændrede ordvalg øger imidlertid hverken præcision eller teoretisk fundament for fænomenet, idet kollaborativ læring gennemgående bruges på samme måde som gruppearbejde, dvs. uden fælles begrebsdannelse. I en oversigt over begrebsudviklingen inden for feltet (Strijbos og Martens 2001) fremgår det således bl.a. at 'cooperative learning' fra 90-erne bliver afløst af 'collaborative learning', uden at de i det undersøgte artikelmateriale kan påvise entydighed i definitioner eller enighed om kriterier for en skelnen. Med enkelte undtagelser er feltet indtil videre meget lidt optaget af læringsteoretiske overvejelser, bortset fra enkelte overordnede henvisninger til konstruktivisme eller socialkonstruktivisme.

Man kan imidlertid ofte tolke de læringsmål, der opstilles i artikler om CSCL, som udtryk for et bagvedliggende læringsteoretisk grundlag. Mange artikler fokuserer på kollaboration om korrekt løsning af en lærerdefineret opgave med kun én løsning, hvilket antyder et behavioristisk grundlag. En anden stor gruppe læringsmål omhandler 'shared understanding', hvilket antyder en socialkonstruktivistisk forståelse, mens begrebet 'shared solution' vil kunne passes ind i en dansk forståelse af gruppearbejde, som den er defineret i Encyklopædien. Disse læringsmål er ikke uproblematiske: Behaviorisme beskæftiger sig for så vidt ikke med læring, men med adfærd, her i form af korrekte opgaveløsninger. Forestillingen om 'shared understanding' lader sig kun begribe som enten det sociale systems forståelse, og dermed ikkeeksisterende når gruppen opløses. Eller også skal man forestille sig, at alle personer har forstået det samme, hvilket må betyde 'sammenflydende bevidstheder' - en absurd forestilling, for hvad skal man så tale om? I praksis vil den fælles forståelse formentlig være tilsyneladende og bygge på autoritære/forføreriske elementer, eller ligefrem bedrageriske $i$ form af ladensom-om. 'Shared conclusion' kan derimod ses som en kommunikativ handling i et socialt system. Til gengæld indebærer den ikke nødvendigvis læring, men består i praksis ofte af en simpel sammenføjning af gruppemedlemmernes individuelle viden.

Indtil videre er vi altså ikke nærmere en forståelse af, hvad det er der gør kollaborativ læring så nødvendig i undervisningssystemet. Men måske er spørgsmålet forkert stillet? 
I en artikel om 'Individual and Social Aspects of Learning' gør Salomon og Perkins (1998) et ambitiøst forsøg på at forholde sig til social læring på et metateoretisk. Udgangspunktet er om der er teoretisk og empirisk belæg for antagelsen af social læring som fænomen - et spørgsmål som besvares ved at vende det om: "If we can raise the question of whether social learning is a valid and viable phenomenon, the opposite question might equally well be raised: Is it not possible that solo learning is just a figment of the traditional laboratory-based psychology on the one hand, and of a socially shared respect for the individual qua individual, on the other?" (Ibid.: 1.) Det overordnede synspunkt bliver efterfølgende at læring må have såvel en social som en individuel side, samt at alle læreprocesser må involvere en 'reciprok spiralrelation' af en mangfoldighed af læreprocesser som understøtter hinanden (ibid.: 16f).

Dette kan formentlig ikke overraske andre end 'the traditional laboratory-based psychology', fordi det også passer med praksis og erfaringer. Synsvinklen finder også støtte i Luhmanns (2000: 98) opfattelse af forholdet mellem psykiske og sociale systemer som co-evolutionært udviklede og dermed dybt forbundne i erkendelse, dannelse af mening - og læring. Både uden for og inden for undervisningsinstitutioner indgår den enkelte i sociale systemer, f.eks. bestående af elev og lærer, elever og lærer (hold eller klasse) eller gruppe uden lærer, hvor både den enkelte og det sociale system kan udfordres til at lære, i det omfang systemerne har en rig og kompleks omverden at trække på. Den helt afgørende forudsætning er dog, at der kommunikeres, da sociale systemer består af kommunikation - og kun af kommunikation.

Luhmanns forståelse af kommunikation adskiller sig fra de gængse kommunikationsmodeller ved at flytte fokus fra 'budskabet' til de selektioner eller valg, som parterne i kommunikationen foretager: valg af information, valg af meddelelse(sform) og valg af forståelse. Kommunikationen bestemmes af den, der foretager valget af forståelse (kaldet 'ego') ved hjælp af en tolkning af forholdet mellem information og meddelelse (foretaget af 'alter ego'). Der er ingen kommunikation, hvis ikke der kommunikeres en forståelse, og indsigt i individers erkendelse eller læring kan kun etableres gennem (yderligere) kommunikation. Forståelse betyder nemlig ikke, at forståelsen er lig med den intenderede information hos alter ego, men handler om egos operationer, som sker ud fra egos autonome og enestående forudsætninger og forventninger.

Principielt adskiller de forskellige typer af sociale systemer sig ikke fra hinanden, og Luhmann kan ikke bruges til at hævde, at kollaborativ læring har særlige kvaliteter frem for klasseundervisning eller forelæsninger. I praksis er klasseundervisning dog næppe vellykket som social læring, da lærere ofte betragter klassen som ét individ i den forstand, at det som enkeltelever svarer, anses for forstået af hele klassen. Omvendt betragter elever læreren som deres personlige lærer og forestiller sig sjældent, at andre elever kan bidrage til deres læring - de er snarere konkurrenter om lærerens opmærksomhed. Læringspotentialet vil kunne mangfoldiggøres, hvis elever/studerende opdager andre elever/studerende som relevante personer for deres læreproces. Kollaborativ læring kan således ud fra en teoretisk betragtning anskues som en øget mulighed for erkendelse og etablering af rigdom eller kompleksitet i læringsmiljøet.

Om muligheden for kollaborativ læring bliver udnyttet er så en anden sag. Det afhænger bl.a. af hvilken form for feedback, der praktiseres i gruppen. Positive feedback-processer i form af bekræftelse og facilitering, samt mål om 'shared understanding', konsensus og gnidningsfrie processer vil næppe befordre kollaborativ læring, men snarere en 'mønstergentagelse'. Derimod kan negative feedback-processer som uenigheder, fejl og tekniske udfordringer være det, der sætter gang i erkendelsesoperationer (se f.eks. Veerman et al. 1999, Thorsteinsson 2000 og Arnseth et al. 2001, samt Rasmussen 1998), hvis ellers såvel de enkelte individer som det sociale system er indstillet på læring og ikke kun på bekræftelse. 
Så jo - der kan gives en læringsteoretisk begrundelse for, at kollaborativ læring findes. Det er imidlertid langt fra et bevis for, at og hvordan kollaborativ læring fungerer i praksis.

\section{Refleksiv og kollaborativ refleksiv læring}

Refleksion er et 'hurraord' i den forstand, at det er blevet modeord inden for læringsteoretisk og pædagogisk forskning - i en grad, så teorierne angiveligt ville bryde sammen uden (Jacobsen, ed., 1997: 7). Ligesom kollaboration/gruppearbejde bliver refleksion opfattet og anvendt på vidt forskellig måde, også hos teoretikere. Jacobsen tolker dette som udtryk for forskellige former for refleksion (ibid.: 159f), mens jeg vil hævde, at det er udtryk for forskellige læringsteoretiske opfattelser. Som kollaborativ læring skal refleksion altså også forstås i sammenhæng med den underliggende læringsteoretiske eller pædagogiske tankegang.

I forhold at begribe hvad der ud fra en læringsteoretisk betragtning foregår i kollaborative læringssammenhænge, er det efter min opfattelse nødvendigt at operere med to refleksionsbegreber, alt efter om vi taler om individuel refleksion i den enkelte person, eller om kollaborativ - og kommunikativ - refleksion i gruppens sociale system. Fælles er, at refleksionen kan foregå på to niveauer: Som selvbeskrivelse eller selvfremstilling og som refleksivitet eller 2.ordensrefleksion - tænkning om tænkning eller kommunikation om kommunikation (Luhmann 2000: 507f).

Den individuelle (kognitive) refleksion beskrives af Illeris som eftertanke, defineret som en særlig akkomodativ proces til løsning af et problem, der ikke bliver løst i den oprindelige situation, og hvor forståelsen først kan håndteres efter en tidsforskydning, hvor "eftertanken trænger sig på" (Illeris 1999: 41). Dette er i overensstemmelse med erkendelsesbegrebet hos Luhmann, idet "erkendelse naturligvis (er) meget langsommere end den operation som ligger til grund for den" (Luhmann 1997: 60). I forhold til kollaboration kommer individuel refleksion til syne som selvfremstilling.

Den kollaborative refleksion er i sagens natur ikke bundet til en tidsforskydning, da den foregår i kommunikation, og derfor skal kunne foregå løbende uden tilbagetrækning til eftertanke. Det ændrer imidlertid ikke ved, at også den kollaborative refleksionsproces sættes i gang af noget, der kræver omstrukturering (Christiansen et al. 1997: 187). Her er det imidlertid ikke eftertanken, der trænger sig på, men kommunikationen, og den kan resultere i læring både hos de involverede personer og i gruppens sociale system.

Begge former for refleksion er således udløst af noget, der 'trænger sig på', hvilket betyder, at det måske nok er muligt at tilrettelægge pædagogiske processer, der sigter på refleksion af såvel individuel som kollaborativ karakter. Men det vil ikke være muligt at forudsige refleksionen, endsige læringsresultatet, selv om det på den anden side heller ikke vil være muligt at undgå refleksiv læring.

I den forbindelse finder jeg det afgørende at tage hensyn til Batesons begreb om læringsvaner. For ganske vist kan Batesons forestilling om individets løbende opbygning af læringsvaner i en vis forstand sidestilles med refleksiv læring (Bateson 1998: 80ff) - heraf netop umuligheden af at undgå refleksiv læring. Men samtidig er læringsvanen 'dybt rodfæstet' og kan bestå hele livet. Begrebet kan udbygges med henvisning til at systemstrukturer hos Luhmann (2000: 345) er dannet af forventninger. Under en forventning om læring/ikke-læring sker det, at "forventninger der er parate til læring, stiliseres som kognitioner. ... Derimod bliver forventninger, der er uvillige til læring, stiliseret som normer." (Ibid.: 375f). Normer eller læringsvaner vil således være en faktor, der skal tages i betragtning i enhver analyse af læring. 
Både på det selvfremstillende plan og på et kollaborativt plan opfatter jeg således refleksion og refleksiv læring som teoretiske muligheder. Det er imidlertid ikke det samme som at fænomenerne findes i virkeligheden, som det fremgår i den efterfølgende redegørelse for kollaboration og refleksion i et udsnit af den asynkrone, skriftlige CSCL-virkelighed.

\section{Kollaboration og kollaborativ refleksiv læring i virkeligheden}

\section{Terminologisk forbemærkning}

Jeg anvender i det følgende betegnelsen 'virtuel' for den computermedierede kontekst og 'real' for den kontekst, som er karakteriseret ved fysisk tilstedeværelse.

\section{Kort beskrivelse af empiri og metode}

Det empiriske materiale stammer fra en distribueret masteruddannelse, hvor information og kommunikation fortrinsvist foregår i konferencesystemet FirstClass. Konferencer oprettes og organiseres både af studiet og af de studerende. På første semester er det teoretiske arbejde organiseret $\mathrm{i}$ en hovedkonference med fire underkonferencer (hold), underopdelt i studiegrupper. Studiegrupperne skal desuden lave et pilotprojekt, og det er et enkelt af disse pilotprojektforløb, som er undersøgelsens primære analyseobjekt. Pilotprojektets læringsaspekt er defineret som en træning i projektarbejdsformen samt i anvendelsen af FirstClass som arbejdsredskab til projektarbejde, og er altså primært en opbygning af virtuelle og kollaborative kompetencer.

Undersøgelsen er todelt. Jeg har foretaget registreringer af konferencens 109 indlæg i form af tabeller over de oplysninger jeg kunne få ved at betragte konferencens struktur, herunder også de enkelte indlægs historik - hvem der har skrevet det, hvornår det er afsendt, hvem der har åbnet (læst) det hvornår, af hvem og hvornår der er svaret, samt om, af hvem og hvornår vedhæftede filer er åbnet. Tabellerne har dannet grundlag for en analyse og tolkning af kommunikation og kollaboration ud fra dens 'formelle' sider, såsom håndtering af de teknologiske værktøjer eller forskellige tidsmæssige forhold - som hvor tit der læses og skrives.

Den anden del af undersøgelsen er således først foretaget, efter at jeg havde konkluderet på den første analyse. Her er der tale om en indholdsanalyse og -tolkning af samtlige 109 indlæg med henblik på en vurdering af kollaborationens forløb og karakter, samt af tegn på refleksion og læring. De to analyser er altså kun delvist overlappende, men det er selvfølgelig interessant, at de ikke altid er overensstemmende, dér hvor de handler om det samme.

Ud fra teoretiske overvejelser opstillede jeg på forhånd en række undersøgelsesparametre eller sigtepunkter for især den første del af undersøgelsen, bl.a. kollaborativ 'tæthed' i form af antal af og tidsafstand mellem indlæg, fordelingen mellem meddelende (indlæg der ikke svares på), reaktive (indlæg som der svares på, men som ikke afføder yderligere indlæg) og interaktive indlæg (indlæg der indgår i en længere tråd, og som viser tilbage til tidligere indlæg, jvf. Rafaeli og Sudweeks 1997) samt udnyttelsen af dén tidsmæssige fleksibilitet, som er et af de stærke argumenter for brugen af virtualitet i kollaborative sammenhænge.

Derudover har jeg forsøgt at have øjnene åbne for mønstre og fænomener, som kunne sige noget interessant. Bl.a. viser det sig, at man til en vis grad kan kompensere for umuligheden af at vurdere, om et indlæg er læst eller bare er åbnet, uden at det er læst, ved at se på om vedhæftede filer er åbnet - i hvert fald hvis der sendes så mange vedhæftede filer (27) som i denne gruppe. Er de ikke det, kan indlægget vurderes som 'ikke-læst'. Det er også muligt ved hjælp af de kvantitative data at gruppere personerne efter karakteren af deres aktivitet. Hovedparten af de vedhæftede oplæg er således skrevet af én person, mens hovedparten af de reaktive indlæg er skrevet af én (anden) person. En væsentlig faktor i gruppens kollaborative 
mønster er dog givetvis, at de er uerfarne med FirstClass og ikke hverken får eller opsøger hjælp til at anvende systemets faciliteter.

Bearbejdningen af de kvantitative optællinger såvel som indholdsanalyserne er sket under en kvalitativ synsvinkel, hvor det styrende har været validiteten i forhold til målet om at vurdere omfang og karakter af den konkrete kollaboration samt iagttage mulig refleksion. Undersøgelsen har reliabilitet i forhold til, hvad der faktisk er foregået i konferencen. Men da gruppen har holdt enkelte reale møder, og da jeg ikke kan udtale mig om gruppens repræsentativitet, er analyser og konklusioner ikke autoritative udsagn om hvordan kollaboration og refleksion i FirstClass er - højst hvad det også er.

\section{Analyse af de kvantitative data}

Der tegner sig et billede af en kollaboration præget af lav aktivitet, især i starten hvor der er op til 11 dage mellem indlæggene. Hvor kollaborationen er tættest, er der højst seks indlæg pr. dag. Det virker som et uforpligtende samarbejde, hvilket støttes af, at enkeltpersoner jævnligt nedsætter deres aktivitetsniveau til sporadisk og selektiv læsning, samt af at to personer ikke læser alle vedhæftede filer. Kun i få situationer læser alle personer indlæg samme dag de er lagt ind. Tendensen til meddelende indlæg (70 ud af 109) og reaktive - i modsætning til interaktive - tråde peger i samme retning, ligesom det store antal vedhæftede filer, hvoraf $2 / 3$ ikke besvares.

Der er store indbyrdes forskelle mellem de enkelte personers aktivitetsform - gruppen udnytter i dén grad fleksibiliteten i den asynkrone skriftlige kommunikation, hvilket kan give anledning til at overveje, om studiets vægt på kollaboration er i overensstemmelse med den fleksibilitet, som de studerende forventer af studiet. På den anden side kan det undre, at der er en overvejende tendens til at aktiviteten foregår i normal arbejdstid, ligesom der er lav aktivitet $\mathrm{i}$ weekender og ferier, hvor man ellers kunne forvente aktivitet fra deltidsstuderende med fuldtidsarbejde.

Endelig bliver pilotprojektets formål om øget fortrolighed med FirstClass næppe opfyldt. Det viser sig som dårlig anvendelse af overskrifter - de er for ens og for intetsigende - $\mathrm{i}$ brugen af vedhæftede filer, ligesom den usikre brug af redskaber til trådning af indlæggene ikke er befordrende for overblik og refleksion.

En forklaring på aktivitetsformen kunne være en tendens til at opfatte studieaktivitet som produktion af oplæg og opgaver og i mindre grad debat, afsøgning, udveksling etc. Dette kan ses som et udtryk for de studerendes læringsvaner og/eller hænge sammen med opgavestrukturen i holdkonferencen, hvor der stort set ikke foregår andet end opgaveaflevering og lærerrespons. Der kunne således se ud til at mangle opmærksomhed fra studiets side på de studerendes håndtering af såvel konferencesystemet FirstClass som de nødvendige samarbejds- og studieformer.

\section{Analysen af kommunikationens indhold}

Indholdsanalysen bekræfter den strukturelle uoverskuelighed og den manglende fortrolighed med FirstClass, selv om der er en anelse mere sammenhæng i forløbet end overskrifter og den manglende trådning lader ane. Mange svar viser sig desuden at være hurtige kommentarer af typen "hvor er du dygtig, når du sådan får stillet tingene op". Omkring 30\% af kommunikationen består desuden af mødeaftaler eller lignende. De 109 indlæg falder kollaborativt set i en række faser, som jeg ikke kan gå i detaljer med her. Analysen vil således kun blive antydet med udgangspunkt i den måde, samarbejdet indledes på. Udsagn, der i det følgende er i dobbelte citationstegn, er citater fra et konferenceindlæg, men jeg undlader her at differentiere mellem de forskellige personer. 
Den indledende sekvens på 17 indlæg er første forsøg på en afklaring af problemfeltet med udgangspunkt i referatet af et realt møde, hvor emne og arbejdsprocedure er fastlagt: "Alle kan fremsende forslag til problembaggrund og vi skriver løs på dokumentet efter forgodtbefindende. Vi vil så diskutere og bygge videre på dette/disse dokumenter." Proceduren virker umiddelbart dårligt tilpasset til konferencesystemet, hvor man kan foretage en afklaring i en mere løs, men stadig skriftligt fastholdt diskussion, før man begynder at skrive dokumenter.

Der kommer fire oplæg inden for seks dage, men der kommer kun respons på et af dem - efter otte dage. Oplæggene er meget forskellige. Et enkelt er formuleret direkte i FC, virker åbent, men går alligevel ud fra at diskussionen skal foregår med netop dét udgangspunkt. Et andet er et metapræget oplæg om problemformulering, der munder ud i et forslag til præcisering af emnet. De øvrige må betegnes som egentlige (udkast til) problemformulering. Der er primært tale om markering af synspunkter - hver person kommer med en 'selvfremstilling' og nogle foreslår en problemformulering, før problemområdet overhovedet er afgrænset i fællesskab. Hvad der i den kvantitative analyse blev tolket som debat af oplæggene i form af fem sammenhængende indlæg viser sig at være en isoleret debat om et teoretisk begreb. Det er et af de få debatterende forløb i den forstand, at der deltager flere end to. Men kommunikation er alligevel reaktiv, da kommentarerne vedrører ét enkelt indlæg.

Sekvensen varer 20 dage, og dens forslag falder til jorden af mangel på reaktioner. Indlæg handler typisk om eget oplæg eller selvfremstilling, ikke om forståelse af andres. Den mislykkede proces skyldes måske en forkert tænkt arbejdsproces. Det bliver en forhindring for en fælles udveksling, at alle starter med at formulere sig selvfremstillende, og dermed bliver fokuseret på, hvad de selv er nået frem til. Havde udgangspunktet været et enkelt løst oplæg, ville processen måske være forløbet anderledes. Det hjælper heller ikke at oplæggene er vedhæftede filer, der skal læses uden for FirstClass. Slet ikke når to personer ikke læser knap halvdelen af de vedhæftede filer.

Næste sekvens (11 indlæg) lægger op til aflevering af udkast til gruppens vejleder. Et gruppemedlem forsøger sig med en ny start i form af en opsummerende mosaik over første sekvens samt et forslag til emneafgrænsning og "beder om jeres refleksioner foranlediget af mit nørkleri. Hvis I vil være så søde?” Den første reaktion kommer seks dage efter: "jeg kan som fagperson ikke have noget imod den problemformulering" (min kursivering, AE). Pilotprojektet anskues her som et fagligt projekt inden for eget praksisfelt, ikke som en studieaktivitet mhp. kollaborativ læring. Kort før deadline aftales så alligevel, at den opsummerende mosaik skal afleveres som udkast - dog efter at man har "fjernet de ikke så flatterende, men rigtige hints til gruppemedlemmerne".

Meldingerne på dette stadium er tvetydige. Der er stadig ingen afklaring af problemområdet. Den opsummerende mosaik er tænkt som et redskab til kollaborativ refleksion, men bliver aldrig brugt sådan. Der gribes kun fat i oplæggets afsluttende forslag til emneafgrænsning, selv om oplægget lægger op til diskussion af alle de formuleringer der har været på banen, og den dårlige proces i form af manglende respons tages ikke op. De forskellige selvfremstillinger er ikke til forhandling og provokerer heller ikke til fælles overvejelser. Der vendes tilbage til dem i hele forløbet.

Næste kollaborative aktivitet i FirstClass kommer efter et realt møde som resulterer i et oplæg i form af "hurtigt nedskrevne tanker efter vores lille efterfrokostsnak". Der lægges op til, at de andre skal skrive videre på dokumentet (en vedhæftet word-fil), men da der kommer kritik af det skrevne, kommer man ikke videre, og der afholdes et nyt realt møde - der er stadig ikke er enighed om problemafgrænsning og arbejdsmetode. Mødet refereres som "rå og usødede" 
notater af den, der har leveret kritikken, og som også har påtaget sig at lave et nyt oplæg. Man synes at være indstillet på, at aktivitet og gensidig ansvarlighed skal højnes. Den kollaborative proces har herefter i en kort periode lidt større deltagelse, lidt mere accept af kritik og lidt mindre tendens til at blive hængende $\mathrm{i}$ gamle formuleringer. Interaktivitet i form af reference til også andres indlæg stiger, og der er ansatser til kollaborativ refleksion over, hvad en problemformulering egentlig er. Men aktiviteten er primært koncentreret på to personer, som til gengæld viser tegn på kollaborativ læring. De øvrige er ikke rigtig en del af processen, og da den endelige deadline nærmer sig, vender de tilbage til deres oprindelige formuleringer fra de allerførste indlæg. Den endelige aflevering bliver således et 'kludetæppe', der stritter i mange retninger, og som for hovedpartens vedkommende består af, at hver enkelt har grebet tilbage til teori fra tidligere uddannelses- eller erhvervssammenhænge.

\section{Opsummering og diskussion af kollaboration, refleksion og refleksiv læring}

Kollaborativt fravær viser sig at være et voldsomt problem. Man går fejl af dagsordenen, når man ikke læser alle indlæg. ligesom det omvendt bliver et problem for de kollaborativt aktive, når inaktive blive aktive igen, og insisterer på ellers kasserede formuleringer eller dagsordener.

Så kollaboration er sårbar og kræver kommunikativ tilstedeværelse konstant og aktivt, hvilket kun en enkelt lever op til. Hun tilfører jævnligt gruppen input af teoretisk eller metodisk art, og selv om også hun i starten er utilbøjelig til at kommentere andet end egne synspunkter, reagerer hun gradvist også kritisk på andres indlæg. Hun føler sig formentlig tvunget ud i rollen som initiativtager af de øvriges lave aktivitet, men bidrager omvendt netop derved til, at deres aktivitet ikke øges, fordi hendes kritik opfattes som 'nedvurdering'. Det er tydeligt, at der er tale om helt forskellige læringsvaner: én som primært er indstillet på teoretisk, kognitiv læring gennem kritisk refleksion - gerne kollaborativt, men det er ikke det primære. Den anden har primært udgangspunkt i de studerendes arbejdspraksis og er orienteret mod kollaboration med henblik på konsensus, men ikke indstillet på kritik. Læringsvaner opbygges gennem hele livet, og måske er (især nogle af) de studerende dybt præget af en elevrolle, der forventer (positiv) tilbagemelding - fra lærer, ikke fra medstuderende - på egne udspil, men ikke er indstillet på at give tilbagemelding til andre og derfor ikke påtager sig rollen som 'ego'.

Det spiller også en rolle, at konflikter søges løst på reale møder. Her bilægges stridigheder, og der opbygges en konsensus, men i virtualitetens nøgne kommunikation afsløres den som tilsyneladende. De reale møder ser faktisk ud til at forhindre en fælles forståelse af problemområdet ved at sætte processen mod tydeliggørelse af uenigheder i stå.

Det hænger bl.a. sammen med den måde der reflekteres på. Der er overvejende tale om individuelle refleksioner, som lægges frem som selvfremstillinger og er svære at forholde sig til, fordi de repræsenterer en læring, der ér sket i stedet for at være åbne oplæg til kollaborativ refleksion og læring. Først og fremmest er det svært at ændre de selvfremstillinger, som fra starten af forløbet lægges ind som oplæg. I den fortsatte diskussion af grundlaget for projektet er forventningen ikke-læring i forskelsforventningen om læring eller ikke-læring. Selvfremstillingerne sætter sig med andre ord fast som norm.

Her bliver forskellen mellem real og virtuel kommunikation tydelig. I real kommunikation vil en selvfremstilling løbende blive afbrudt, modsagt eller mødt med andres selvfremstilling, og dermed korrigeret kollaborativt i en refleksiv kommunikation. Det er sværere i virtualiteten, hvor man kan skrive uden afbrydelser og gense tidligere holdninger. Betingelserne for kommunikation er således forskellig i de to kontekster. Den individuelle og den kollaborative refleksion kommer måske nemmere i karambolage med hinanden, når kommunikationen er skriftlig. Ved at overgå til individuel selvfremstilling i form af de vedhæftede filers færdig- 
formulerede og 'opgaveagtige' oplæg, ødelægges den kollaborative refleksion, der netop lever af at være løbende, og derfor er sårbar overfor den individuelle refleksions tidsdimension og den mindre tætte kollaboration.

Vælger man at gå ind i en møjsommelig, kontingent, kompleks og af og til smertefuld skriftlig, refleksive kommunikation med henblik på forståelse, kan der opstå kollaborativ refleksion: A skriver til B: "Jeg kan da godt se når du sådan konkretiserer det du loeser at fokus er forkert." Et sjældent eksempel på at den usandsynlige kommunikation sandsynliggøres gennem omhyggelig kommunikation af det forståede - her i 3 led: A kommunikerer, B kommunikerer sin (kritiske) forståelse og A kommunikerer refleksivt sin forståelse af hvad B har forstået. Hvis hovedparten af interaktionen var sådan, kunne der være basis for megen kollaborativ refleksiv læring.

Realt er det tilsyneladende sværere at fastholde fornemmelsen af kontingens eller åbenhed. På de reale møder kommunikeres der med henblik på konsensus og i stedet for en negativ feedback, der kan fastholde reelt eksisterende uenigheder som dagsorden for det videre forløb, er en konsensussøgende positiv feedback måske nok befordrende for effektivitet $\mathrm{i}$ forhold til produktet, men den fører ikke til samme læring. Refleksiv læring eller erkendelse sker nok først, når der ikke kan findes en smutvej til at undgå den (Bateson) eller når en voldsom akkomodativ reorganisering trænger sig på (Illeris). Man kunne hævde, at gruppen bruger de reale møder som 'smutvej'.

Men selv om der kan siges meget om gruppens problemer og manglende tætte og forpligtende kollaboration, så er der faktisk ingen tvivl om, at der foregår læring. Mange forskellige slags læring og meget helt uventet, irriterende, og derfor måske netop refleksiv læring. Også læring der ikke nødvendigvis er hensigtsmæssig eller i overensstemmelse med forventningerne hos studium og lærere. Jeg forestiller mig f.eks., at gruppens medlemmer i kommende projekter vil søge mod samarbejdspartnere med samme læringsvaner eller måske helt undgå kollaboration.

Pilotprojektets officielle læringsmål er kollaborative kompetencer, og der er flere almene udsagn om en sådan læring: "Jeg fornemmer at det trods alt har været en lærerig proces for os men måske mest på områder som vi ikke i første omgang havde forestillet os." Udsagnet kan tolkes som refleksiv læring. Det er ikke forventet læring, men noget der er sat i gang af 'noget ufuldendt'. Hos enkelte personer kan læringen spores i ændringer af deres måde at kommunikere og interagere på, men alle udtrykker, at de har lært af processen. Det forbliver blot oftest skjult, hvad de har lært. Konkrete formuleringer af læring er sjældne, men kan f.eks. tage form af refleksiv kommunikation om forholdet mellem studium og arbejdspraksis som vejleder: "under alle omstændigheder lærer jeg meget som jeg kan bruge i min forståelse af de studerende når jeg vejleder dem".

På det kognitive område er det et problem at gruppen ikke har - og heller ikke på noget tidspunkt søger at opbygge - en fælles diskurs eller 'grounding' (Dillenbourg 1999). Teoretisk læsning indgår ikke i gruppens kommunikation, bortset fra de selvfremstillinger der ikke diskuteres. Fælles teoretisk diskurs ser i øvrigt ud til at være et problem på hele holdet, ikke blot i gruppen. Teoretiske opgaver uddelegeres, afleveres og afføder ingen debat - kun lærerreaktioner. Holdopgaverne bliver heller ikke læst! De afleveres som vedhæftede filer, og åbnes af mellem 4 og 11 af de 22 studerende på holdet. Eneste undtagelse er et indlæg der er skrevet direkte i FirstClass og er åbnet af 15 ! 


\section{Er kollaborativ refleksiv læring kun en teoretisk mulighed?}

Kollaborativ refleksiv læring findes således - både i teorien og empirisk. Men den er svær, sårbar og - i den undersøgte gruppe - sjælden, og den opstår ikke af sig selv. Med forbehold over for empiriens spinkelhed vover jeg her nogle bud på hvilke betingelser, der i hvert fald skal være opfyldt:

Først og fremmest skal der kommunikeres - af alle og hele tiden. Kun derved eksisterer det sociale system. De involverede personer skal være indstillet på læring, også i forhold til andre studerende, og de skal være i stand til at frigøre sig fra elevrollens fokusering på læreren samt fra en forventning om bekræftelse og normopfyldelse. Dette skal på den anden side støttes af den måde holdkonferencer og andre konferencer med lærerdeltagelse er organiseret og fungerer på.

Kommunikativt skal de involverede personer være indstillet på, at det er ego, der har ansvaret for kommunikationen, så der skal fokus på den eller de, der svarer (eller ikke svarer) i stedet for på den, der meddeler sig Der skal opbygges en forståelse for virkningen - kollaborativt og individuelt - af forskellige former for feedback, så kollaborationen ikke sættes i stå af bekræftende kommentarer eller oplevelsen af 'nedvurdering'. Omvendt kræves også bevidsthed om forskellen mellem individuel refleksion i form af selvfremstilling og kollaborativ refleksion i form af refleksiv kommunikation - for meget vægt på den individuelle refleksion kan bremse for den kollaborative.

Derudover skal der fokus på forskellen og forholdet mellem real og virtuel kollaboration. Problemer i det virtuelle grupperum løses ikke gennem reale møder, hvis problemerne bryder ud igen, når man er tilbage i den virtuelle kommunikation.

Det er formentlig vitalt, at vejledere og lærere behersker det anvendte kommunikationssystems kollaborative værktøjer, herunder værktøjer til overblik og strukturering, så de kan bistå de studerende med råd og dåd.

For at vende tilbage til det indledende citat fra Encyklopædien, så er det næppe holdbart, når den almindelige opfattelse i praksis og diskurs er, at danske elever/studerende gennem hyppigt at blive udsat for gruppearbejde udvikler en kollaborativ, og for den sags skyld også refleksiv eller virtuel kompetence som medløbende læring eller socialisering. Denne opfattelse indebærer nemlig ofte en logisk cirkelslutning, hvor det, der skal læres, samtidig er forudsætningen for, at læringen kan foregå. I Det Virtuelle Gymnasium forestiller man sig eksempelvis på den ene side, at en ny, virtuel pædagogik skal "fremme elevernes ansvarlighed, selvstændighed, kreativitet og samarbejdsevne, samtidig med at elevernes beredskab til at håndtere forandringer styrkes ...” (Det Virtuelle Gymnasium 2001: 33). På den anden side forudsættes det, at eleverne allerede besidder disse kompetencer: "Det er en forudsætning, at læringsmiljøet er præget af ansvarsfølelse og selvstændighed, der giver eleverne en arena for fordybelse og opøvelse af faglige, almene, sociale og personlige kompetencer." (Ibid.: 23f). Det forbliver uklart, hvor og hvordan ansvarlighed og selvstændighed skal opøves eller læres, når de både er læringsmål og forudsætning.

Derfor vil det være min konklusion, at undervisningssystemet, institutionerne og lærerne må påtage sig en undervisning, der kan give de bedst mulige betingelser for læring - også når læringsmålet som i den foreliggende undersøgelse er kollaborative og virtuelle kompetencer. 


\section{Litteratur}

Arnseth, Hans Christian, et al. "Collaboration and Problem Solving in Distributed Collaborative Learning." European Perspectives on Computer-Supported Collaborative Learning. Proceedings of the First European Conference on Computer-Supported Collaboraative Learning. Eds. Pierre Dillenbourg, Anneke Eurelings \& Kai Hakkarainen. Maastricht: Universiteit Maastricht, 2001.

$<$ http://www.mmi.unimaas.nl/euro-cscl/Papers/8.doc>. (Downloaded 20/9 2003)

Bateson, Gregory. "De logiske kategorier for læring og kommunikation." Fra laeringens horisont - en antologi. Ed. Mads Hermansen. Århus: Klim 1998. 63-91.

Birch Andreasen, Lars. "Virtuelt samarbejde i en flydende modernitet". Uddannelse, laering og IT 26 forskere og praktikere gør status på området. København: Uddannelsesstyrelsen. Undervisningsministeriet, 2002.

$<$ http://www.it-strategi.uvm.dk> .... Perspektiver og erfaringer ... virtuelle læringsmiljøer. (Downloaded 18/9 2003).

Christiansen, Iben Maj \& Lene Nielsen \& Ole Skovsmose. "Ny mening til begrebet refleksion i matematikundervisningen?" Refleksive loereprocesser. Ed. Jens Christian Jacobsen. København: Forlaget politisk revy, 1997. 173-190.

Den Store Danske Encyklopcedi. København: Gyldendal 1994-2001.

Det Virtuelle Gymnasium. Vision og strategi. København: Uddannelsesstyrelsens temahæfteserie nr.37, 2001.

Dillenbourg, Pierre. "What do you mean by 'collaborative learning'?". Collaborative Learning: Cognitive and Computational Approaches. Ed. P. Dillenbourg. Oxford: Elsevier, 1999. 1-19.

$<$ http://tecfa.unige.ch/tecfa/publicat/dil-papers-2/Dil.7.1.14.pdf $>$ (Downloaded 20/9 2003).

Ejsing, Anne. Kollaborative og refleksive laereprocesser i CSCL-omgivelsers asynkrone skriftlige kommunikation. Aalborg Universitet: Masteruddannelsen i Læreprocesser, VCL 2001.

Heise, Inge. Loererliv. København: Undervisningsministeriet, Gymnasieafdelingen 1998.

Historie med samfundskundskab i det almene gymnasium. Evalueringsrapport 2001. København: Danmarks Evalueringsinstitut, 2001.

Hermansen, Mads, ed. Fra Loeringens Horisont. Århus: Klim, 1998.

Illeris, Knud. Problemorientering og deltagerstyring. København: Munksgaard, 1976.

Illeris, Knud. Laering. Roskilde Universitetsforlag, 1999.

Jacobsen, Jens Christian, ed. Refleksive loereprocesser. København: Politisk Revy, 1997.

Luhmann, Niklas. "Barnet som medie for opdragelsen". Laring, samtale, organisation -

Luhmann og skolen. Ed. Jens Rasmussen. København, 1993.

Luhmann, Niklas. „Autopoiesis“. Iagttagelse og paradoks. Niklas Luhmann. København, 1997.

Luhmann, Niklas. Sociale systemer. København: Hans Reitzels Forlag, 2000.

Rafaeli, Sheizaf \& Fay Sudweeks. "Networked Interactivity". Journal of Computer-Mediated Communication. Volume 2, Number 4, March, 1997.

$<$ http://www.ascusc.org/jcmc/vol2/issue4/rafaeli.sudweeks.html $>$ (Downloaded 20/9 2003).

Rasmussen, Jens. Socialisering og lcering i det refleksivt moderne. København: Unge Pædagoger, 1997.

Rasmussen, Jens. "Radikal og operativ konstruktivisme". Pcedagogiske teorier. Ed. Niels Jørgen Bisgaard. Værløse: Billesø \& Baltzer, 1998. 120-137.

Rognhaug, Berit. "Kunnskabssyn og yrkesutøvelse. Refleksjoner over kunnskabsbegrepet". Refleksive loereprocesser. Ed. Jens Christian Jacobsen. København: Politisk Revy, 1997. 110-134. 
Salomon, Gavriel \& David N. Perkins. "Individual and Social Aspects of Learning". Review of Research in Education, vol. 23, 1998.

$<$ http://construct.haifa.ac.il/ gsalomon/indsoc.htm> (Downloaded 20/9 2003).

Schibbye, Anne Lise Løvlie. "Fra begrensning til avgrensning: Synspunkter på grensesetting og barns utvikling av selvrefleksjon". Refleksive loereprocesser. Ed. Jens Christian Jacobsen. København: Politisk Revy, 1997. 135-147.

Sorensen, Elsebeth K. "Interaktion og læring i virtuelle rum". At undervise med IKT. Ed. Simon B. Heilesen. København: Samfundslitteratur, 2000. 235-255.

Strijbos, J.W. og R.L. Martens. 2001: "Group-based learning: Dynamic interaction in groups". European Perspectives on Computer-Supported Collaborative Learning. Proceedings of the First European Conference on Computer-Supported Collaboraative Learning. Eds. Pierre Dillenbourg, Anneke Eurelings \& Kai Hakkarainen. Maastricht: Universiteit Maastricht, 2001.

$<$ http://www.mmi.unimaas.nl/euro-cscl/Papers/154.doc> (Downloaded 20/9 2003).

Thorsteinsson, Uffe. "Ændring af undervisningsform med brug af IT". At undervise med IKT. Ed. Simon B. Heilesen. København: Samfundslitteratur, 2000. 145-178.

Thyssen, Ole. "Hjørnesten i Niklas Luhmanns systemteori”. Iagttagelse og paradoks. Niklas Luhmann. København, 1997.

Tyler, Ralph. Undervisningsplanlaegning. København: Chr. Ejlers Forlag, 1977.

Veerman, A.L., J.E.B. Andriessen \& G. Kanselaar. "Collaborative Learning through Computer- Mediated Argumentation". Proceedings og the Computer Support for Collaborative Learning (CSCL) 1999 Conference. Eds. C. Hoadly \& J. Roschelle. Dec. 12-15 1999, Stanford University, Palo Alto, California. Mahwah, NJ: Lawrence Erlbaum Associated.

$<$ http://kn.cilt.org/csc199/A77/A77.HTM> (Downloaded 20/9 2003).

Wenger, Etienne. "En social teori om læring”. Tekster om Laering. Ed. Knud Illeris. København: Gyldendal, 2000. 151-161.

Ziehe, Thomas. "Om prisen på selv-relationel viden - Afmystificeringseffekter for pædagogik, skole og identitetsdannelse". Refleksive laereprocesser. Ed. Jens Christian Jacobsen. København: Politisk Revy, 1997. 